\title{
Penggunaan Antibiotik yang Kurang Tepat pada Peternakan Babi di Kota Kupang, Nusa Tenggara Timur
}

\author{
(INAPPROPRIATE USE OF ANTIBIOTICS IN A PIG FARM IN KUPANG CITY, \\ EAST NUSA TENGGARA)
}

\author{
Annytha Detha ${ }^{1 *}$, Diana Agustiani Wuri', Filomena Ramos ${ }^{2}$, \\ Desi Biru², Margie Mila Meha², Anita Lakapu \\ ${ }^{1}$ Bagian Ilmu Penyakit Hewan dan Kesehatan Masyarakat Veteriner, \\ ${ }^{2}$ Mahasiswa Koasistensi, Program Pendidikan Dokter Hewan, \\ Fakultas Kedokteran Hewan, Universitas Nusa Cendana \\ Jl. Adi Soecipto, Penfui, Kupang Nusa Tenggara Timur \\ *Email: detha.air@staf.undana.ac.id
}

\begin{abstract}
Misuse of antibiotics has the potential to accelerate the emergence of types that are resistant to inappropriate drugs. This study aims to evaluate the inappropriate use of antibiotics in pig farms in the City of Kupang, East Nusa Tenggara. This antibiotic use evaluation study was conducted from March to May 2018. This study was conducted on 100 pig farmers spread across 6 (six) districts in Kupang City. The sampling technique was done by stratified random sampling method based on the characteristics or types of the population. This research used descriptive analysis method from the results of questionnaire data collection that had been filled out by pig farmers in Kupang City. Based on the results obtained that $84 \%$ of pig farmers or respondents did not know the function of antibiotics, and 83\% of respondents did not know that the administration of antibiotics must be done with the supervision of a veterinarian. The results also showed that $86 \%$ of pig farmers buy antibiotics without a veterinarian's prescription, with the type of antibiotics most often used were the tetracycline and sulfonamide groups. These results conclude that dominant respondents apply antibiotics without veterinary supervision, which can contribute to the spread of resistant bacteria so that it adversely affects human health.
\end{abstract}

Keywords: antibiotic; antibiotic resistance; residue; pig farms

\begin{abstract}
ABSTRAK
Penggunaan antibiotik yang mengacu pada pemberian yang tidak tepat sehubungan dengan obat, dosis, interval, durasi dapat mempercepat munculnya jenis yang resistan terhadap obat yang tidak tepat. Penelitian ini bertujuan untuk mengevaluasi penggunaan antibiotik yang tidak tepat pada peternakan babi di wilayah Kota Kupang, Nusa Tenggara Timur. Studi evaluasi penggunaan antibiotik ini dilaksanakan dari bulan Maret hingga Mei 2018. Penelitian ini dilakukan pada 100 peternak babi yang tersebar di enam kecamatan yang ada di Kota Kupang. Teknik pengambilan sampel dilakukan dengan metode penarikan sampel secara acak bertingkat (stratified random sampling) didasarkan pada karakteristik atau tipe dari populasi. Penelitian ini menggunakan metode analisis deskriptif dari hasil pengumpulan data kuesioner yang telah diisi oleh peternak babi yang ada di Kota Kupang. Berdasarkan hasil yang diperoleh, sebesar $84 \%$ peternak babi tidak mengetahui fungsi antibiotik, dan sebanyak $83 \%$ responden tidak mengetahui bahwa pemberian antibiotik harus dilakukan dengan pengawasan dokter hewan. Hasil penelitian juga menunjukkan bahwa $86 \%$ peternak babi dapat dengan bebas membeli antibiotik di berbagai toko obat hewan yang ada di Kota Kupang tanpa menyertakan resep dari dokter hewan dengan jenis antibiotik yang paling sering digunakan ialah golongan tetrasiklin dan sulfonamida. Penelitian ini menunjukkan bahwa masih banyak peternak yang mengaplikasikan antibiotik tanpa pengawasan dokter hewan, sehingga dapat menyumbang penyebaran bakteri resistan yang berdampak buruk bagi kesehatan manusia.
\end{abstract}

Kata-kata kunci: antibiotik; resistansi antibiotik; residu; peternakan babi 


\section{PENDAHULUAN}

Penggunaan antibiotik pada peternakan diperlukan untuk mengobati kejadian penyakit infeksi kausa bakteri (Economou dan Gousia, 2015). Antibiotik pada umumnya bermanfaat dalam mengobati infeksi bakteri yang rentan dan perlu diimbangi oleh penggunaan rasional (Mund et al., 2017). Namun, penggunaan antibiotik yang tidak tepat meningkatkan resistansi antibiotik (Meeker et al., 2016; Van Wyk, 2015). Beberapa penelitian telah membuktikan bahwa pemberian antibiotik yang tidak sesuai makin banyak terjadi di beberapa negara (King et al., 2018; Van Wyk, 2015) yang tidak saja terjadi pada kasus penyakit pada manusia, namun juga pada hewan (Hoelzer et al., 2017; King et al., 2018).

Masalah terbesar apabila infeksi yang terjadi pada manusia dan hewan berubah menjadi resistan terhadap antibiotik sehingga sulit diobati. Hal ini telah menyebabkan krisis kesehatan secara menyeluruh yang diakibatkan semakin bertambah banyak bakteri yang resistan antibiotik pada beberapa tahun terakhir (Bacanlý dan $\mathrm{Ba}^{\circ}$ aran, 2019). Kondisi makin buruk apabila bakteri yang telah resistan ternyata dapat menyebar dengan cepat dan berpotensi menyebabkan kesulitan pengobatan bagi penyakit-penyakit infeksi pada manusia dan hewan yang disebabkan bakteri (Durso dan Cook, 2014). Penyebaran bakteri resistan dimungkinkan karena adanya fenomena alami yang terjadi pada saat bakteri memperbanyak diri dan ketika saat sifat resistan dipertukarkan (Gebeyehu et al., 2015).

Masalah resintansi bakteri terhadap antibiotik terjadi karena kurangnya penelitian terkait resistansi antibiotik, kurangnya komitmen, kurangnya pengendalian infeksi, penggunaan antibiotik yang tidak sesuai dosis, antibiotik berkualitas buruk, dan pengawasan yang buruk dan lemah (Hadi et al., 2013). Penggunaan dan penyalahgunaan antibiotik mempercepat munculnya jenis mikrob yang resistan terhadap obat (Van Wyk, 2015). Penggunaan antibiotik yang tidak tepat mengacu pada pemberian yang tidak tepat sehubungan dengan obat, dosis, interval, dan durasi pemberian (Gebeyehu et al., 2015). Penyelidikan ilmiah sudah jelas menunjukkan bahwa ketika antibiotik tidak memadai, terapi tidak efektif, strain resistan muncul, superinfeksi terjadi sehingga pada akhirnya total biaya terapi meningkat (Economou dan Gousia, 2015).
Kegagalan pengobatan pada ternak dapat disebabkan karena peternak memberikan pengobatan tanpa resep dokter dan dilakukan tidak dalam pengawasan dokter hewan (Fernandez, 2013). Hal yang serupa dapat terjadi pada peternak yang menggunakan antibiotik untuk ternaknya. Pemahaman peternak yang minim tentang penggunaan antibiotik dapat menjadi salah satu penyebabnya. _Masalah resistansi juga disebabkan adanya penggunaan obat hewan yang tidak sesuai, dan produk hewan tersebut dikonsumsi oleh manusia (Manyi-Loh et al., 2018). Pola transmisi ini telah banyak dibuktikan di beberapa wilayah di Indonesia (Aprillian et al., 2015; Fikri et al., 2018), termasuk wilayah kota Kupang (Kallau et al., 2018).

Penggunaan antibiotik yang tidak sesuai oleh peternak dapat juga berdampak buruk pada kesehatan masyarakat. Oleh karena itu penting sekali dilakukan penelitian yang mengevaluasi penggunaan antibiotik pada hewan terutama ternak yang produknya banyak dikonsumsi masyarakat. Penelitian ini bertujuan untuk mengevaluasi penggunaan antibiotik yang tidak tepat pada peternakan babi di wilayah Kota Kupang, Nusa Tenggara Timur.

\section{METODE PENELITIAN}

\section{Waktu Tempat dan Jenis Penelitian}

Studi evaluasi penggunaan antibiotik ini dilaksanakan dari bulan Maret hingga Mei 2018. Penelitian ini dilakukan pada peternakan babi di enam kecamatan yang ada di Kota Kupang yaitu Kecamatan Alak, Kecamatan Maulafa, Kecamatan Oebobo, Kecamatan Kota Raja, Kecamatan Kelapa Lima, dan Kecamatan Kota Lama.

\section{Teknik Pengambilan Sampel}

Teknik pengambilan sampel dilakukan dengan metode penarikan sampel secara acak bertingkat (stratified random sampling) didasarkan pada karakteristik atau tipe dari populasi (Thrusfield dan Brown, 2017). Berdasarkan metode teknik yang dipilih, pengambilan sampel pada tingkat kecamatan dilakukan secara acak untuk memilih rukun warga (RW). Besaran sampel ditentukan secara proporsional yaitu 100 sampel yang tersebar di Kecamatan Alak berjumlah 33 peternak, Kecamatan Maulafa 25 peternak, Kecamatan Oebobo 21 peternak, Kecamatan Kelapa Lima 
delapan peternak, Kecamatan Kota Raja sepuluh peternak dan Kecamatan Kota Raja tiga peternak.

\section{Analisis Data}

Penelitian ini menggunakan metode analisis deskriptif yaitu menginterpretasikan hasil pengumpulan data dari kuesioner yang telah diisi oleh peternak babi yang ada di Kota Kupang. Alat yang digunakan adalah kuesioner sebagai alat untuk mengumpulkan data serta perangkat komputer untuk menganalisis data. Jenis data yang dikumpulkan berkaitan dengan pengetahuan peternak babi tentang antibiotik, pengetahuan peternak tentang antibiotik dan resep dokter hewan, alasan penggunaan antibiotik oleh peternak babi, cara penggunaan antibiotik oleh peternak babi, dan jenis antibiotik yang digunakan peternak. Hasil penelitian selanjutnya disajikan dalam tabel dan gambar.

\section{HASIL DAN PEMBAHASAN}

\section{Pengetahuan peternak tentang antibiotika}

Berdasarkan hasil yang diperoleh, peternak babi atau responden yang mengetahui bahwa antibiotik sebagai obat untuk penyembuhan penyakit infeksi bakteri sebanyak $4 \%$, dan $84 \%$ lainnya tidak mengetahui fungsi antibiotik. Kebanyakan responden yang tidak mengetahui apa itu antibiotik dan fungsi antibiotik untuk penyembuhan penyakit bakteri, sangat berkorelasi dengan penyuluhan atau informasi yang diberikan pada peternak. Hasil penelitian juga menunjukkan bahwa dari sebanyak $84 \%$ responden, peternak umumnya belum pernah mengikuti kegiatan penyuluhan yang diberikan pemerintah maupun lembaga non pemerintah

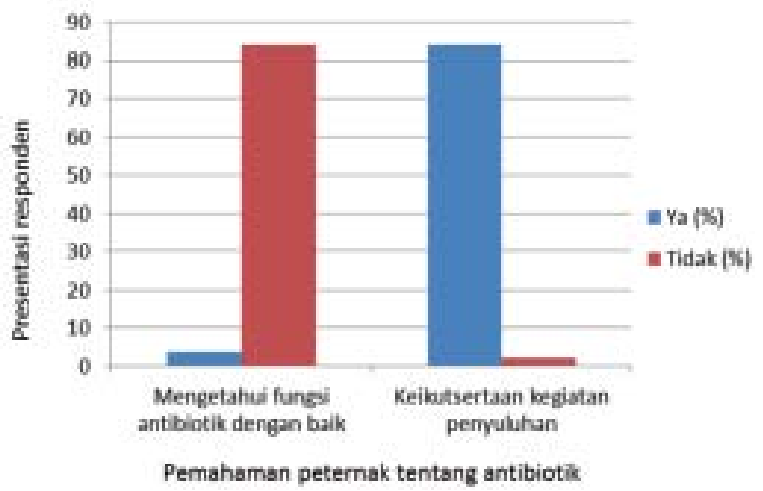

Gambar 1. Pengetahuan peternak babi di Kota Kupang tentang fungsi antibiotik dan keikutsertaan dalam penyuluhan dan hanya $2 \%$ yang pernah mengikuti kegiatan penyuluhan (Gambar 1)

Informasi mengenai pengetahuan peternak tentang antibiotik sangat penting karena dapat menjadi rujukan tindakan preventif untuk penggunaan antibiotik yang tidak tepat dosis. Tindakan preventif dapat dilakukan dengan meningkatkan edukasi dalam bentuk penyuluhan pada peternak sehingga memengaruhi cara berpikir dan berdampak pada tindakan nyata (Ediset et al., 2017; Rahmawati et al., 2016).

\section{Pengetahuan Peternak tentang Antibiotik dan Resep Dokter Hewan}

Berdasarkan hasil penelitian, diketahui sebanyak $86 \%$ peternak babi tidak mengetahui bahwa pemberian antibiotik harus di bawah pengawasan oleh dokter hewan, sedangkan $4 \%$ lainnya sudah mengetahuinya. Adapun responden yang tidak mengetahui bahwa pemberian antibiotik harus di bawah pengawasan dokter hewan sebanyak $83 \%$, sedangkan 3\% lainnya sudah mengetahuinya.

Pengetahuan peternak babi mengenai antibiotik termasuk dalam kategori rendah. Berdasarkan data yang diperoleh terdapat lebih banyak responden yang tidak mengetahui bahwa pemberian antibiotik harus dilakukan oleh dokter hewan ataupun pemberiannya harus di bawah pengawasan dokter hewan. Resep antibiotik untuk ranah peternakan perlu diawasi penggunaannya oleh dokter hewan (CIWF, 2011)

Penggunaan antibiotik oleh masyarakat sangat bergantung pada pengetahuan masyarakat mengenai antibiotik dan cara penggunaan antibiotik yang benar. Hal ini sangat berperan dalam mencegah penggunaan

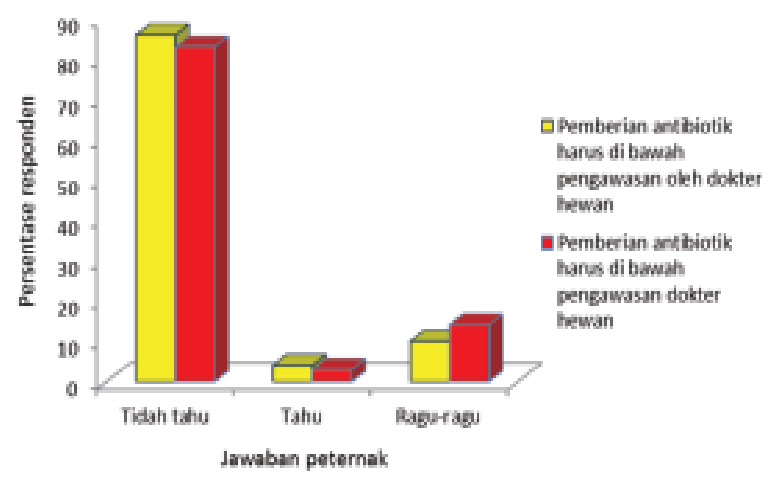

Gambar 2. Pengetahuan peternak babi di Kota Kupang tentang antibiotik dan resep dokter hewan 
antibiotik yang tidak sesuai (Bacanli dan $\mathrm{Ba}^{\circ}$ aran, 2019). Kegiatan penyuluhan merupakan salah satu langkah edukasi yang menginformasikan pada masyarakat tentang penggunaan antibiotik.

\section{Alasan Penggunaan Antibiotik oleh Peternak Babi}

Terkait dengan alasan penggunaan antibiotik, peternak yang memberikan antibiotik tanpa pengawasan dokter hewan karena berbagai sebab. Terdapat beberapa alasan maupun kendala dari peternak sehingga tidak melapor kepada petugas kesehatan hewan, yaitu peternak memilih untuk melakukan pengobatan sendiri sesuai dengan pengalamannya maupun berdasarkan informasi dari masyarakat lain mengenai cara pengobatan ternak yang sakit sebanyak $63 \%$, selanjutnya karena tidak adanya pusat kesehatan hewan (Puskeswan) terdekat sebanyak 27\%. Alasan lain karena tidak ada petugas kesehatan hewan di Puskeswan dengan persentase sebanyak 6\% (Tabel 1).

Tabel 1. Sebaran alasan peternak babi di Kota Kupang tidak melapor kepada petugas kesehatan hewan saat ternak sakit
No Alasan Responden

1. Dapat melakukan pengo-

batan sendiri

2. Tidak ada Puskeswan terdekat $27 \%$

3. Tidak ada petugas di Puskeswan $6 \%$

4. Biaya pemeriksaan yang tinggi
Persentase Responden

$63 \%$

$7 \%$
$6 \%$
-

Berdasarkandata, sebanyak 57\% peternak babi di Kota Kupang tidak pernah melapor kepada petugas kesehatan hewan dalam hal ini dokter hewan maupun petugas peternakan, 39\% peternak babi pernah melapor kepada petugas kesehatan hewan tetapi tidak selalu, sedangkan $4 \%$ peternak babi selalu melapor ke petugas kesehatan hewan apabila ternak mereka sakit (Tabel 2).

\section{Cara Penggunaan Antibiotik oleh Peternak Babi}

Berdasarkan data diketahui bahwa terdapat $86 \%$ peternak babi dapat dengan bebas membeli antibiotik di berbagai toko obat hewan yang ada di Kota Kupang tanpa menyertakan resep dari dokter hewan dan $4 \%$ lainnya pemberian
Tabel 2. Persentase peternak babi di Kota Kupang yang melapor pada petugas kesehatan hewan saat ternak sakit

\begin{tabular}{llr}
\hline No $\quad$ Pelaporan kepada petugas & $\begin{array}{r}\text { Persentase } \\
\text { responden }\end{array}$ \\
\hline 1. & Ya, selalu & $4 \%$ \\
2. & Pernah, tidak selalu & $57 \%$ \\
3. & Tidak pernah & $39 \%$ \\
\hline
\end{tabular}

antibiotik oleh dokter hewan. Responden yang secara bebas dapat membeli antibiotik, dapat secara bebas pula dalam mengaplikasikan antibiotik bagi ternak sakit dan juga pemberiannya tidak di bawah pengawasan dokter hewan. Begitu pula dengan dosis dan frekuensi pemberian yang secara bebas ditentukan oleh peternak sendiri.

Terkait dengan hewan yang telah diobati oleh peternak, berdasarkan hasil penelitian diperoleh hasil bahwa ternak yang tidak sembuh setelah diberikan antibiotik sebanyak $16 \%$, ternak yang pernah sembuh tetapi tidak selalu dalam setiap pemberian antibiotik yaitu sebanyak $68 \%$ sedangkan ternak yang sembuh sebanyak 2\%. Apabila ternak yang diberikan antibiotik tidak sembuh, sebanyak $32 \%$ peternak menyembelih untuk dikonsumsi sendiri, 29\% peternak menjual ternaknya, dan 18\% dibiarkan saja, serta hanya 5\% saja peternak yang melapor pada petugas (Tabel 3).

Bakteri atau mikroflora pada ternak yang telah mengalami resistansi antibiotik dapat menyebarkan bakteri resistan pada konsumen yang mengonsumsi pangan asal hewan tersebut.

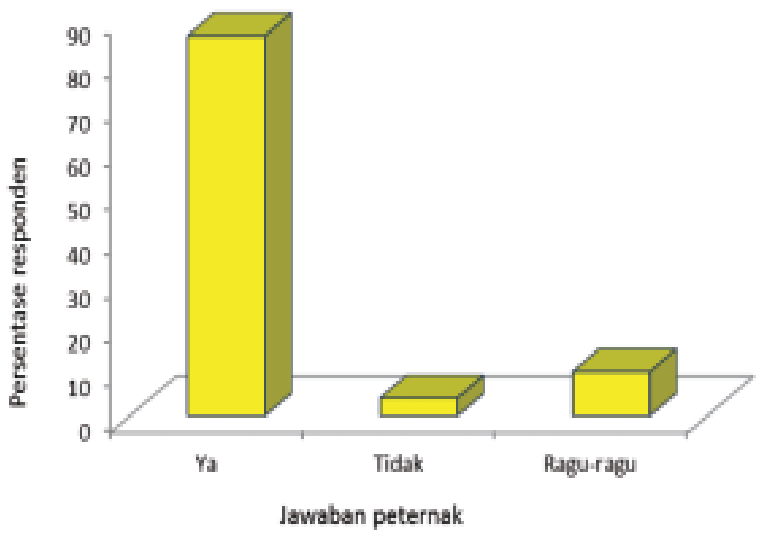

Gambar 3. Presentasi pembelian antibiotik melalui resep dan aplikasinya pada ternak babi di Kota Kupang. 
Tabel 3. Tindakan yang dilakukan peternak babi saat pemberian antibiotik tidak menyembuhkan ternak yang sakit

\begin{tabular}{llc}
\hline No & Tindakan peternak & $\begin{array}{c}\text { Persentase } \\
\text { responden }\end{array}$ \\
\hline 1. & Dijual & $29 \%$ \\
2. & Dikonsumsi & $32 \%$ \\
3. & Dibiarkan saja & $18 \%$ \\
4. & Melapor pada petugas & $5 \%$ \\
& (setelah tidak sembuh) & \\
\hline
\end{tabular}

Praktik pengobatan yang tidak sesuai dapat memperpanjang rantai penyebaran bakteri resistan pada manusia dan hewan (Hoelzer et $a l .$, 2017). Masalah lain yang dapat muncul yaitu pada saat hewan diobati dengan antibiotik dan disembelih sebelum masa henti obat berakhir. Apabila hewan tersebut disembelih dan dikonsumsi oleh konsumen menimbulkan residu antibiotik pada produknya yang dapat memicu terjadinya resistansi antibiotik pada bakteri (Bacanlý dan $\mathrm{Ba}^{\circ}$ aran, 2019). Setiap jenis antibiotik memiliki waktu henti obat yang bervariasi, selain karena faktor cara pemberian, dan dosis (Prajwal et al., 2017). Dengan kenyataan yang ada bahwa banyaknya peternak yang memberikan atau mengaplikasikan antibiotik tanpa pengawasan dokter hewan, maka akan sulit pemahaman tata cara penggunaan dan dampak bagi kesehatan manusia. Dengan kenyataan bahwa masih banyak peternak yang mengaplikasikan antibiotik, maka dapat menyumbang penyebaran bakteri resistan yang mengancam kesehatan manusia dan hewan.

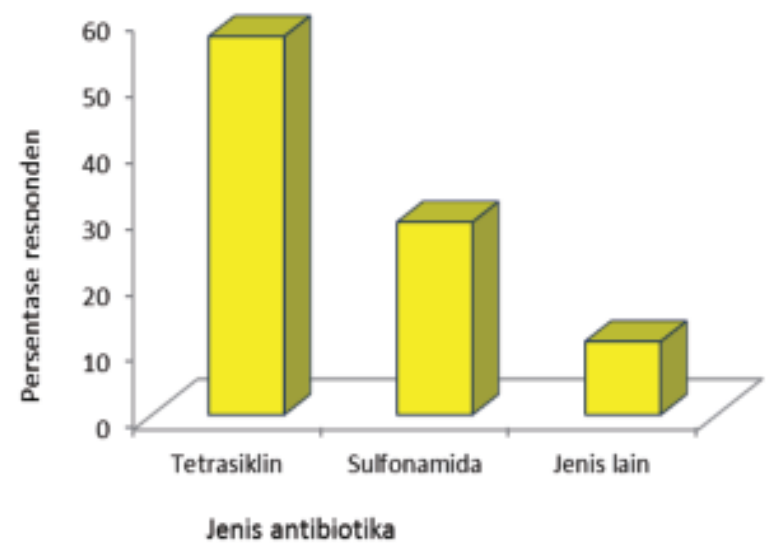

Gambar 4. Jenis nama dagang antibiotik yang digunakan peternak babi di Kota Kupang

\section{Jenis antibiotik yang digunakan peternak babi}

Berdasarkan hasil penelitian menunjukkan bahwa jenis antibiotik yang paling sering digunakan ialah golongan tetrasiklin dengan jumlah sebesar 57\%. Jenis antibiotik lain yang paling sering digunakan ialah golongan sulfonamida sebanyak 29\% dan antibiotic lainnya yaitu 11\% (Gambar 4).

\section{SIMPULAN}

Berdasarkan hasil yang diperoleh, dapat disimpulkan bahwa peternak babi di Kota Kupang kebanyakan tidak mengetahui fungsi antibiotik dan tidak mengetahui bahwa pemberian antibiotik harus dilakukan dengan pengawasan dokter hewan sehingga praktik ini dapat menyumbang penyebaran bakteri resistan terhadap antibiotik yang berdampak buruk bagi kesehatan manusia dan hewan.

\section{DAFTAR PUSTAKA}

Aprillian R, Rahardjo D, Koesdarto S. 2015. Evaluation of Salmonella sp contamination and its antibiotics resistance patterns isolated from broiler meat sold at wet market in center of Surabaya. Indonesian Journal of Tropical and Infectious Disease 5(6): 143146.

Bacanli $\mathrm{M}, \mathrm{Ba}^{\circ}$ aran N. 2019. Importance of antibiotic residues in animal food. In Food and Chemical Toxicology 125: 462-466.

CIWF. 2011. Antibiotics In Public Health and Animal Welfare. Compassion In World Farming. November: 1-43.

Durso LM, Cook KL, 2014. Impacts of antibiotic use in agriculture: What are the benefits and risks? Current Opinion in Microbiology 19(1): 37-44.

Economou V, Gousia P. 2015. Agriculture and food animals as a source of antimicrobialresistant bacteria. Infection and Drug Resistance 8: 49-61.

Ediset E, Jaswandi J, Heriyanto E, Basyar B. 2017. Peningkatan produktivitas peternak sapi di daerah transmigrasi Lubuk Aur Sitiung I Kabupaten Dharmasraya. Logista 1(1): 11.-19. 
Fernandez BAM. 2013. Studi penggunaan antibiotik tanpa resep di Kabupaten Manggarai dan Manggarai Barat-NTT. Calyptra 2(2): 1-17.

Fikri F, Purnama MTE, Saputro AL, Hamid IS. 2018. Identifikasi Escherichia coli dan Salmonella spp pada karkas sapi di rumah potong hewan di Banyuwangi dan resistensi terhadap antibiotika. Jurnal Sain Veteriner 36(1): 123-128.

Gebeyehu E, Bantie L, Azage M. 2015. Inappropriate use of antibiotics and its associated factors among urban and rural communities of Bahir Dar city administration, northwest Ethiopia. PLoS ONE 10(9): 1-14

Hadi U, Kuntaman K, Qiptiyah M, Paraton H. 2013. Problem of antibiotic use and antimicrobial resistance in indonesia: are we really making progress?. Indonesian Journal of Tropical and Infectious Disease 4(4): 5-8.

Hoelzer K, Wong N, Thomas J, Talkington K, Jungman E, Coukell A. 2017. Antimicrobial drug use in food-producing animals and associated human health risks: What, and how strong, is the evidence? In $B M C$ Veterinary Research 13(1): 211-249.

Kallau NHG, Wibawan IWT, Lukman DW, Sudarwanto MB. 2018. Detection of multidrug resistant (MDR) Escherichia coli and tet gene prevalence at a pig farm in Kupang, Indonesia. Journal of Advanced Veterinary and Animal Research 5(4): 388-396.

King C, Smith M, Currie K, Dickson A, Smith F, Davis M, Flowers P. 2018. Exploring the behavioural drivers of veterinary surgeon antibiotic prescribing: A qualitative study of companion animal veterinary surgeons in the UK. BMC Veterinary Research 14(1): 332-341.

Manyi-Loh C, Mamphweli S, Meyer E, Okoh A. 2018. Antibiotic use in agriculture and its consequential resistance in environmental sources: Potential public health implications. In Molecules 23(4): 795-843.

Meeker D, Linder JA, Fox CR, Friedberg MW, Persell SD, Goldstein NJ, Knight TK, Hay JW, Doctor JN. 2016. Effect of behavioral interventions on inappropriate antibiotic prescribing among primary care practices a randomized clinical trial. Journal of the American Medical Association 315(6): 562570.

Mund MD, Khan UH, Tahir U, Mustafa BE, Fayyaz A. 2017. Antimicrobial drug residues in poultry products and implications on public health: A review. International Journal of Food Properties 20(7): 14331446.

Rahmawati IR, Muksin M, Rizal R. 2016. Peran dan Kinerja Penyuluh Pertanian dalam Memberdayakan Peternak Ayam Petelur di Kabupaten Jember, Provinsi Jawa Timur. Jurnal Penyuluhan 12(2): 183-189.

Prajwal S, Vasudevan VN, Sathu T, Irshad A, Pame K. 2017. Antibiotic residues in food animals: Causes and health effects. The Pharma Innovation Journal 6(12): 1-4.

Thrusfield M, Brown H. 2017. Surveys. In Veterinary Epidemiology. Fourth Edition. Wiley-Blackwell. Hlm. 270-295.

Van Wyk H. 2015. Antibiotic resistance. In $S A$ Pharmaceutical Journal 82(3): 20-23. 